\title{
CONSTITUTIONALE
}

Volume 1 Issue 2, July-December 2020: PP: 107-122

Faculty of Law, Universitas Lampung, Bandar Lampung, Indonesia.

http://jurnal.fh.unila.ac.id/index.php/constitutionale

P-ISSN: 2723-2492

E-ISSN: $2745-9322$

\section{The Urgency of Amendment to Law Number 32 of 2002 concerning Broadcasting as the Legal Umbrella for OTT Services}

\author{
Neysa Tania \\ neysa.205180248@stu.untar.ac.id \\ Universitas Tarumanagara
}

Rio Kurniawan

rio.205180262@stu.untar.ac.id

Universitas Tarumanagara

Submitted: Nov 18, 2020; Reviewed: Dec 3, 2020; Accepted: Dec 222020

\section{Article's Information}

Keywords: Broadcasting; Contitutional Court; Digitalization; Over the Top Service.

\section{DOI:}

https://doi.org/10.25041/constitutionale.v1i2.2125

\section{Abstract}

Digitalization is a global phenomenon that has an impact on changing social conditions. The Broadcasting Bill itself is canceled to be a priority in the 2020 Priority National Legislation Program even though there is a lot of material contained in the law itself needs to be updated immediately according to the times. Therefore, the function of conducting this research is to seek answers in terms of legal certainty regarding the development of legal relations with technological developments in the era of digitalization and constitutional interpretation in the digitalization era that supports sustainable economic development and is in accordance with the Indonesian national identity. This study uses a quantitative juridical analysis method, which is in the form of in-depth research on legal materials and data as usual as normative law. 
Furthermore, the results of the analysis will be linked to the problems in this study to produce an objective assessment to answer the problems in the research. The results of the research show that the OTT services cannot be in the scope of Law Number 32 of 2002 concerning Broadcasting, therefore the Constitutional Court must play a strategic role in carrying out rapid and precise reforms so that statutory norms can be consistent with the development of society, especially due to developments. Digital technology. The most ideal and relevant constitutional interpretation of the Judicial Review case against this law would be: Consensualism, Prudential and Futuristic with an emphasis on legal certainty for Over the Top (OTT) services and on socioeconomic impacts significant impact on the general welfare. It is necessary to revise the Broadcasting Law with the intention of maintaining national integration to establish a national broadcasting system that guarantees the creation of a just, equitable, and balanced national information order in order to realize social justice for all Indonesian people.

\section{A. Preliminary}

Law develops following times and human needs. This is consistent with the theory of Progressive Law which asserts that law is made more responsive to very urgent social needs and to problems of social justice while maintaining the institutional results that have been achieved by rule based on law. ${ }^{1}$ Laws that move dynamically will give serious attention to following the development of society in various forms that keep up with the times. Currently, the world is entering an era of technological disruption that shifted in the era of the Industrial Revolution 4.0. The World Economic Forum (WEF) calls the Industrial Revolution 4.0 a CyberPhysical System-based revolution which is broadly a combination of three domains, namely digital, physical, and biological. The term industry 4.0 first came from a project initiated by the German government to promote the computerization of manufacturing. According to Prof. Klaus Martin Schwab, German engineer, and economist, who is also the founder of the World Economic Forum, today we live in an age of technological change that fundamentally changes the way we live, work and relate to one another. Where the convergence of digital technology

\footnotetext{
${ }^{1}$ Sanusi, Kus Rizkianto, and Kanti Rahayu, "HUKUM YANG RESPONSIF TERHADAP REVOLUSI INDUSTRI 4.0 DALAM PERSPEKTIF PANCASILA," Prosiding Seminar Nasional Hukum Transendental 2019, 2019.
} 
is accompanied by breakthroughs in science and biology, bringing up a new way of life, and also changing the meaning of being human. ${ }^{2}$ The essence of Industry 4.0 is a combination of physical and digital technology through analytics, artificial intelligence, cognitive technology, and the Internet of Things (IoT) to create an interconnected digital company capable of making more informed decisions. With the internet, the Information and Communication Technology industry is now leading to convergence. At first, each of these technologies seemed to run separately (linearly) from one another, but now all technologies are convergent. The form of telematics convergence is marked by the birth of community products which in the end will also result in creating a new market which support the development of the economic system from a traditional economic system based on the manufacturing industry towards a digital economy system which based on information, intellectual creativity and science. ${ }^{3}$ Indonesia itself has committed to implementing Industry 4.0 as an effort to build a manufacturing industry that has global competitiveness. This commitment is marked by the launch of "Making Indonesia 4.0" by President Joko Widodo in 2018 as a road map and strategy for Indonesia in entering the ongoing digital era.

In order to survive in this growing digital era, the media must also follow the flow of digitalization so that they are not out of date. Because nowadays, the media are no longer oneway, but two-way. This requires synergy between conventional media and digital media. Likewise, with television broadcasting media which must adapt to technological developments and competencies, especially those based on digital platforms. In response to this, the Ministry of Communication and Information Technology of the Republic of Indonesia prepared a "digital TV infrastructure roadmap" starting in 2009 until the end of 2018 as a road map for the implementation of migration from analog to digital television broadcasting systems.

According to the Minister of Communication and Information, Johnny G. Plate, this digitalization of broadcasting will help maintain its existence with a newcomer called Over the Top (OTT) Business. ${ }^{4}$ OTT itself is a form of a convergence of technology that is increasingly unified in this digital era, where the digital platform can be simply understood as a service with content in the form of data, information, or multimedia that operates on the internet network of a telecommunications operator. The OTT service itself can be divided into at least 3 (three) categories, namely:

1. Applications such as WhatsApp, Line, Telegram, Skype, Facebook, Twitter, Instagram, and so on;

2. Content / video-on-demand / streaming such as Youtube, HOOQ, Netflix, Viu, and so on; or

3. Services such as Gojek, Grab, Uber, and so on.

The current polemic is regarding the regulation of the OTT service itself. Where then PT Rajawali Citra Televisi (RCTI) and PT Visi Citra Mitra Mulia (iNEWS TV) submitted a request for a judicial review to the Court regarding the OTT service arrangement. The Petitioner believed that the provisions in Article 1 paragraph (2) a quo do not cover internet-based broadcasting services that are currently emerging. This internet-based service gave birth to many digital platforms known as OTT (over the top) services that should be included in the broadcasting regime because OTT also carries out broadcasting activities (delivering messages in the form of sound, image, or sound and image). The difference between conventional broadcasting activities lies in the broadcasting method used. This lawsuit has been filed in the

\footnotetext{
${ }^{2}$ Klaus Schwab, The Fourth Industrial Revolution, New York: Crown Business 2017, hal. iv

${ }^{3}$ Edmon Makarim, Pengantar Hukum Telematika: Suatu Kompilasi Kajian (Jakarta: Raja Grafindo Persada, 2010).

${ }^{4}$ CNN Indonesia. "Penyiaran Digital Indonesia Tertinggal Dibanding Malaysia." Teknologi, cnnindonesia.com, 26 July 2020, www.cnnindonesia.com/teknologi/20200725073801-185-528807/penyiaran-digital-indonesia-tertinggal-dibandingmalaysia. Accessed 4 Oct. 2020.
} 
Constitutional Court and the inaugural session was held on June 22, 2020. The petitioners said that the provisions of this article caused constitutional harm due to unequal treatment between conventional broadcasters and Internet-based audiovisual service providers in Indonesia.

This then sparked controversy from various groups, both from experts, government, and the wider community. Because if the lawsuit is approved by the Constitutional Court, many parties are concerned that Law Number 32 of 2002 (Broadcasting Law) will threaten freedom of expression, which is in accordance with the 1945 Constitution of the Republic of Indonesia (UUD 1945), which is a Grundnorm. The State of Indonesia, in Article 28E of the 1945 constitution, states that: "Everyone has the right to freedom of belief, to express thoughts and attitudes, according to their conscience, and everyone has the right to freedom of association, assembly, and expression." and will also deviate from the main spirit of making Law Number 32 of 2002 concerning Broadcasting itself.

Law Number 32 of 2002 concerning Broadcasting has been passed since eighteen years ago. In the vulnerable eighteen years, it cannot be denied that technologies, mass media, and people's lives have changed tremendously. Law is required to be able to follow developments in the field of technology by always anticipating the development of new technology and technology in the future. Regulation of the application of technology is the responsibility of the ruler (state/government) to provide it, in order to bring benefits to society, without doubt, that the technology used is illegal technology and will result in legal problems, both for those who create, offer, and use the technology. ${ }^{5}$

\section{B. Discussion}

1. Reasons OTT services cannot be the scope of Law Number 32 the of 2002 concerning Broadcasting

"Indonesia is the State of Law". This is explicitly stated in Article 1 Paragraph 3 of the 1945 Constitution. This then shows how central the legal position and position are in the course of the life of the nation and state, especially in order to regulate the life of a country for the better. As the legal basis for the State of Indonesia, the constitution functions as a "Grundnorm" that regulates the entire order and every action of the government and society which is governed whose content is a reflection of the constitutionalism adhered to by Indonesia. ${ }^{6}$ According to A. Hamid S. Attamimi, the importance of a constitution or Basic Law is as a handler and limit giver, as well as how state power should be run. ${ }^{7}$ Therefore, all legislative processes starting from the making to implementing the Law (UU) must be based on these constitutional basic principles and if they deviate from these basic principles, the Law is deemed unconstitutional and violates the 1945 Constitution.

As a constitutional state, Indonesia also upholds human rights and constitutional rights contained in the 1945 Constitution. In Article 28D of the 1945 Constitution, it is stated that "Everyone has the right to recognition, guarantee, protection and legal certainty that is just and equal treatment before the law." Therefore, if the public considers that their constitutional rights and/or authorities have been impaired by the enactment of the law, they can submit a Judicial Review to the Constitutional Court. ${ }^{8}$

\footnotetext{
5 F.H. Edy Nugroho, "KEMAMPUAN HUKUM DALAM MENGANTISIPASI PERKEMBANGAN TEKNOLOGI," Jurnal Paradigma Hukum Pembangunan 1, no. 2 (August 31, 2016).

6 Jimly Ashiddiqie, Konstitusi dan Konstitusionalisme Indonesia, (Jakarta: Konstitusi Press, 2005), hlm. 26-27.

${ }^{7}$ Fajrudin, “ARTI PENTING KONSTITUSI DALAM SEBUAH NEGARA,” Al Qisthas: Jurnal Hukum Dan Politik 8, no. 1 (February 2019), http://jurnal.uinbanten.ac.id/index.php/alqisthas/article/view/1613.

8 Tata Cara dan Syarat mengajukan Judicial Review dapat dilihat di UU Nomor 24 Tahun 2003 tentang Mahkamah Konstitusi
} 
This is why PT Visi Citra Mulia (INews TV) and PT Rajawali Citra Televisi Indonesia (RCTI) submitted a Judicial Review on Monday, 22 June 2020, at the Constitutional Court Building of the Republic of Indonesia with case number 39 / PUU-XVIII / 2020 against several Article in Law Number 32 of 2002 concerning Broadcasting. In their lawsuit, the Petitioners questioned Article 1 point 1 of the Broadcasting Law which reads "Broadcast is a message or series of messages in the form of sound, picture, or sound and picture or in the form of graphics, characters, whether interactive or not, which can be received through the receiving device. broadcast." For various kinds of OTT services, especially the content/video-ondemand/streaming category, which basically also produces broadcast content so that it should be included in the broadcasting regime. However, the difference between conventional broadcasting activities lies in the method of transmission used, where OTT services use the network from the Internet. The Petitioners also considered Article 1 point 2 of Law Number 32 of 2002 concerning Broadcasting to be ambiguous and create legal uncertainty. The absence of broadcasting legal certainty for internet-based broadcast providers (OTT) such as Youtube, Instagram, Netflix and Facebook, and other Streaming Social Media Platforms, whether these services fall into the definition of broadcasting as regulated in Article 1 point 2 of the Broadcasting Law or not, This causes broadcasting using the internet to date, such as OTT services, not to be bound by the Broadcasting Law.

In addition, the Petitioner also considers that the Broadcasting Law in effect is contrary to Article 1 paragraph (3), Article 27 paragraph (1), Article 28D paragraph (1), and Article 28I paragraph (2) of the 1945 Constitution due to different treatment between the Petitioners. as a conventional broadcasting operator with a broadcast operator using the internet. Yet if we refer to Article 28D Paragraph 1 of the 1945 Constitution, it is said that "Everyone has the right to recognition, guarantees, protection and legal certainty that is just and equal treatment before the law." This is what made the Petitioners feel constitutionally disadvantaged. Based on the case above, a polemic arises whether OTT services can be equated with conventional broadcasting and can be regulated in Law Number 32 of 2002 concerning Broadcasting.

The basis of the function of healthy information service itself is Law No. 32 of 2002 concerning Broadcasting. If we do a historical study, the main spirit of the birth of Law Number 32 of 2002 concerning Broadcasting is that the management of the broadcasting system must be free from various interests because broadcasting is the public domain and is used maximally for the public interest and also the spirit to strengthen local entities in the spirit of autonomy regions with the implementation of a network broadcast system. ${ }^{9}$ Since the enactment of the Broadcasting Law, there has been a fundamental change in the management of the broadcasting system in Indonesia, which in these articles mandate the existence of democratization or decentralization of broadcasting. (previously in Article 7 of Law Number 24 the Year 1997, it reads "Broadcasting controlled by the state whose guidance and control are carried out by the government", indicating that broadcasting at that time was part of an instrument of power used solely for the benefit of the government). This means, the government's power to control the media has also changed and put the public as the main owner and controller of broadcasting operations. Conventional broadcasting institutions such as RCTI and INews in the case mentioned above in Article 16 of the Broadcasting Law are mentioned as Private Broadcasting Institutions, ${ }^{10}$ where basically Private Broadcasting Institutions are institutions that use public frequencies in providing conventional broadcasting services.

In a democratic system, media regulation is basically divided into two major parts, namely media that use the public domain and media that do not use the public domain. Media that do

\footnotetext{
${ }^{9}$ Komisi Penyiaran Indonesia, "Dasar Pembentukan,” Komisi Penyiaran Indonesia, 2017, http://www.kpi.go.id/index.php/id/tentang-kpi/dasar-pembentukan.

10 Lihat Pasal 16 Undang-Undang Nomor 32 Tahun 2002 tentang Penyiaran "lembaga penyiaran yang bersifat komersial berbentuk badan hukum Indonesia, yang bidang usahanya hanya menyelenggarakan jasa penyiaran radio atau televisi."
} 
not use the public domain, for example, books, magazines, newspapers, and films (unless broadcast on television) are regulated by self-regulatory principles. ${ }^{11}$ In broadcasting activities, if a media uses the public domain, the regulations are very strict. This is because the frequency itself, even though it cannot be used up, is a scarce and limited resource. Dominick, Messere, and Sherman illustrate this limitation in the following statement, "Only a finite number or broadcast stations can exist in a certain place in a certain time; too many stations can interfere with one another ". This statement shows that not all parties can use the frequency at the same location and time. ${ }^{12}$ This is in line with the principles of the scarcity theory which asserts that in essence, the number of frequencies on this earth is limited. Therefore, not all individuals can use it. Despite that, we basically have the same right to use it. Determining who can manage a frequency then becomes important because of this conflicting logic. This also makes the basis for a frequency license in broadcasting has a limited period of time, although it can be extended again because when a person or entity has been granted a license to manage a frequency that is limited in nature, then he/she has actually been given a monopoly right by the state to use that frequency within a period of time. certain time.

Then, the existence of an independent regulatory body in Law Number 32 of 2002 concerning Broadcasting regulates that the Indonesian Broadcasting Commission (KPI) as the regulatory body has independence which is clearly stated by the regulation that KPI is an independent state institution, which regulates broadcasting matters, and consists of Central KPIs and Regional KPIs at the Provincial level. Interestingly, for KPIs it is stated directly, supervision of the implementation of their duties, functions, powers, and obligations, namely the Central KPI is supervised by the People's Representative Council (DPR RI), and Regional KPIs are supervised by the Regional People's Representative Assembly (DPRD). ${ }^{13}$

The basis of a healthy information service function is as stipulated in the Broadcasting Law, namely diversity of content and diversity of ownership. These two principles form the basis for every policy formulated by the KPI. Healthy information service based on diversity of content is the availability of diverse information for the public, both based on program type and program content. ${ }^{14}$ This would then be incompatible if OTT services were to be governed by current KPI regulations. Some discussion of the material, namely regarding, shifting focus towards local content creation, and the integration of various technologies such as machine learning and artificial intelligence in OTT services are expected to provide beneficial opportunities for people who also act as content creators in it. The statement "avoiding content that is not in accordance with the norms" is kind of fluid, wherein this case, if you follow KPI's appeal, the streaming platform will have many sensors that deviate from the principle of diversity of content where then the diverse content in this OTT service is mandatory to follow KPI's regulations. This can also expand the KPI's authority as a broadcasting watchdog. Meanwhile, KPI has so far still had problems making regulations for broadcasting and it is feared that it could complicate the problems of the digital broadcasting world. Study Institutions and the Society also agree to state the weak performance of KPI's supervision of broadcast content. KPI only monitors issues that are viral and weak in the enforcement of the Broadcasting Code of Conduct and Broadcast Program Standards (P3SPS).

\footnotetext{
11 Assyari Abdullah, "Pola Kebijakan Digitalisasi Penyiaran Di Indonesia,” ARISTO 8, no. 1 (January 1, 2020): 82, https://doi.org/10.24269/ars.v8i1.2092.

12 Rahayu dan Regulator, Menegakkan Kedaulatan Telekomunikasi \& Penyiaran Di Indonesia : Peta Persoalan Dan Rekomendasi Kebijakan (Depok, Sleman, Yogyakarta: Pemantau Regulasi Dan Regulator Media, 2015), hlm. 176-177.

${ }^{13}$ Zainal Arifin Mochtar, Lembaga Negara Independen, Dinamika Perkembangan Dan Urgensi Penatannya Kembali PascaAmandemen Konstitusi (Jakarta: Rajawali Press, 2016). Hlm. 74

${ }^{14}$ Laurensius Arliman S, "KOMISI PENYIARAN INDONESIA SEBAGAI STATE AUXIALIARY BODIES YANG

MENJAMIN SIARAN YANG LAYAK BAGI ANAK," Veritas et Justitia 3, no. 1 (2017), https://doi.org/10.25123/vej.2528.
} 
Here are some examples of KPI regulations that can contradict the principle of diversity of content and deviates from the democratic spirit of broadcasting:

a) When we watch romance serials/films without kissing scenes that are deemed to violate the 2012 KPI Broadcasting Code of Conduct Article 9, Article 14, Article 16 and Article 21 Paragraph (1) as well as the 2012 KPI Broadcast Program Standard (P3-SPS) Article 9 Paragraph (2), Article 15 Paragraph (1), Article 18 letter g and Article 37 Paragraph (4) letter $\mathrm{f}$.

b) Action films but no acts of violence are deemed to violate Article 23 of P3-SPS. In P3SPS, it is stated that journalistic broadcast programs on coverage of disasters or calamities are prohibited, adding to the suffering or trauma of victims, families, and communities; displays pictures of victims/corpses in detail, and displays images of serious injuries, blood, and/or pieces of organs

c) Series or content that teaches about sex education, but nothing sexually related is deemed to violate the rules of the SPS Article 8 letter $h$, broadcasting institutions containing sexual scenes are prohibited from exploiting and/or displaying certain body parts such as thighs, buttocks, breast, close up and/or medium shot. ${ }^{15}$

Where this will certainly harm the community itself. In fact, currently, Indonesian people have minimal sex education, whereas many as $84 \%$ of adolescents aged $12-17$ have not received sex education. ${ }^{16}$ Often children's rights regarding sexuality information collide with the limited knowledge of parents on the issue of sexuality itself so that parents also feel confused when discussing sexuality issues with their children. To address this problem, content on the Internet can be used as a reference for parents to provide sexual education to their children. Because according to research conducted by the European Expert Group on Sexuality Education, education about sexual activities does not encourage children to have sexual intercourse but can provide comprehensive information on issues of sexuality so that children understand and are able to make wiser decisions in living their lives. ${ }^{17}$

Also nowadays social media and streaming platforms also have content "filter" features that are more sophisticated than television. This is because OTT services have self-regulatory regulations. Like Netflix, where there are additional features for children available on the homepage, which only content that is safe for children is available. If a child wants to watch adult content, this can be stopped by having to enter the passcode on the parent's account that was previously connected to the child's account. It is different from television shows that only use the label BO (General), R (Teenager), 18+ (Over 18 years old) but children can still watch it too. Platforms like Youtube are also quite strict with the rules. If a content creator wants to upload a video, they must first fill in whether the content is suitable for children to watch and whether the content contains sensitive issues. Viewers also have the power to report sensitive/dangerous content, so that the content can be taken down immediately. This means that this platform is cooperative enough in its efforts to protect viewers in order to obtain content that complies with existing regulations in Indonesia. If this lawsuit is approved and executed, KPI as the regulator has the right to refuse and has the right to terminate the OTT service permit if it is not in accordance with KPI's regulations whose regulations are still vague. Indonesia has entered a period of reform; it would be very unfortunate if we were to return to the era of new

\footnotetext{
${ }^{15}$ Read the complete regulation regarding program standard release on Indonesian Broadcasting Commission Regulation Number 01/P/KPI/03/2012 concerning Guidelines for Broadcasting Conduct.

${ }^{16}$ Putri, Adelia. "Riset: 84 Persen Remaja Indonesia Belum Mendapatkan Pendidikan Seks." DetikHealth, detikcom, 18 July 2019, health.detik.com/berita-detikhealth/d-4629842/riset-84-persen-remaja-indonesia-belum-mendapatkan-pendidikan-seks.

17 "Sexuality Education - What Is It?" Sex Education, 2016, www.tandfonline.com/doi/full/10.1080/14681811.2015.1100599. Accessed 12 Oct. 2020.
} 
orders where we can only see the content that the State wants. (At that time, TVRI was the only TV channel in Indonesia). ${ }^{18}$ This also violated Article $28 \mathrm{~F}$ which states "Everyone has the right to communicate and obtain information to develop their personal and social environment, as well as the right to seek, obtain, own, store, process, and convey information using all kinds of channels available. " It then became clear why conventional broadcasting is regulated in the Broadcasting Law but OTT services cannot be covered by Law Number 32 of 2002 concerning Broadcasting because the content and regulations are inadequate to regulate the OTT service.

The basis for the birth of Law Number 32 of 2002 concerning Broadcasting is limited to broadcasting using public frequencies. Therefore, in order for OTT services to be covered by the Broadcasting Law, it is necessary to revise the Broadcasting Law because this Law is currently insufficient to regulate internet-based OTT services. The discourse on digitalization of broadcasting itself has developed since 2007, due to many countries such as Britain and America which have started it since 1998. The Broadcasting Bill itself is canceled to be a priority in the 2020 Priority National Legislation Program. Even though there is a lot of material contained in Law Number 32 of 2002 concerning Broad casting that needs to be updated immediately according to the times. The rapid and significant development of technology greatly affects life and social conditions in society, so that people must follow existing developments. However, this very rapid technological development is not comparable with the government's response in efforts to regulate the development of existing digital technology services. This is in accordance with one of the legal adages which states "Het Recht hinkt Achter de feiten aan", where the law cannot oppose the progress of the times. This is why the legality of several existing digital technology products or services is still in doubt. According to Collingridge, one aspect of novelty that is important from a regulatory perspective towards being behind the law with technological developments is that there are twin obstacles to regulators in responding to new technology.

Collingridge said at an early stage in technology development, the regulation was problematic due to a lack of information about the possible impact of technology. Meanwhile, at a later stage, regulation becomes problematic as the technology will become more entrenched, making any changes requested by regulators difficult to implement. ${ }^{19}$ The number of controversies and the multiple interpretations in Law Number 32 of 2002 concerning Broadcasting can create legal uncertainty. Comprehensively, the direction of changes regarding Broadcasting law on one hand has to respond to the rapid development in digital broadcast technology, the authority of KPI, Government Authority and Regulation of Broadcast Content. Whereas on the other hand, the Law has to consider efficiency, which is as said by Fajar Sugianto in his book "Economic Approach to Law", that in law and economics, the desire to achieve legal goals is not directed towards justice or legal certainty, but towards efficiency. That is, a regulation of law is "good" if it produces justice that becomes a human standard, for example, it succeeds in achieving a maximum social welfare standard. ${ }^{20}$ Therefore, in responding to the lawsuit filed by RCTI and INews TV, the Constitutional Court must be able to play a strategic role in stimulating developments between legal and technology relations so that the law can respond to technology disruption in the era of digitalization more quickly and accurately in order to encourage revision of the Law Broadcast thoroughly.

\footnotetext{
${ }^{18}$ Ivan Aulia Ahsan, and Irfan Teguh. "Alat Kekuasaan Bernama TVRI.” Tirto.Id, Tirto.id, 24 Aug. 2018, tirto.id/alatkekuasaan-bernama-tvri-cUvu. Accessed 12 Oct. 2020.

${ }^{19}$ Audley Genus and Andy Stirling, "Collingridge and the Dilemma of Control: Towards Responsible and Accountable Innovation,” Research Policy 47, no. 1 (February 2018): 61-69, https://doi.org/10.1016/j.respol.2017.09.012.

${ }^{20}$ Mochamad Riyanto, "ARAH REVISI UNDANG-UNDANG PENYIARAN DALAM PERSPEKTIF HUKUM EKONOMI," SPEKTRUM HUKUM 16, no. 1 (July 15, 2019): 60, https://doi.org/10.35973/sh.v16i1.1127.
} 


\section{Solutions For The Ott Services To Be Part Of The Scope In The Broadcasting Law}

A lot of people especially those who use social media platforms to express themselves and earn a living, rejected the lawsuit. This can be seen from the petition circulating on social media, where the petition has been signed by more than $80 \%$ of its achievements to reject RCTI's lawsuit because they feel that the lawsuit is very unusual. ${ }^{21}$ According to Jeremy Bentham, "it is the greatest happiness of the greatest number that is the measure of right and wrong." This is not in accordance with the purpose of the law to provide the greatest benefit and happiness to as many members of the community as possible. If OTT services are included in Law Number 32 of 2002 concerning Broadcasting, one of the impacts is that it will hinder economic growth and can cause an increase in unemployment in Indonesia because this OTT service has a great influence on the government and people who make a living using these services. ${ }^{22}$ Gadjah Mada University (UGM) Communication Science lecturer Wisnu Prasetya also considered that the RCTI and iNews lawsuit was wrongly targeted. This contradicts the basic objective of making Law Number 32 of 2002 concerning Broadcasting, namely regulating the use of a limited number of public frequency networks. Meanwhile, the OTT network or internet frequencies are unlimited. This could lead to overlapping if OTT services were included in Law Number 32 of 2002 concerning Broadcasting. The internet can also place all uploads as broadcasts, not only audio-visuals, as is done by radio and television, which has the potential for all uploads in the form of text or images to violate the law if they do not get permission from Law Number 32 of 2002 concerning Broadcasting. The inclusion of OTT services into Law Number 32 of 2002 concerning Broadcasting will not be constitutional because it violates the public's right to express opinions on social media, and supports business monopolistic practices.

In order to face the rapidly and ever-growing new media services and business models, governments inevitably have to make decisions and choices that has to not only take into account the interests of providers to offer their services but also the viewer's interest in receiving information. This balancing act by national regulators can lead to social, political, and economic considerations, as well as cultural perceptions. In this case, if OTT services fall into the realm of regulation of Law Number 32 of 2002 concerning Broadcasting, it will cause more disadvantages to the public. Therefore, there is an urgency to immediately revise the Broadcasting Law so that OTT services can be covered by the legal umbrella of the Broadcasting Law itself.

Although there is an urgency to immediately revise the Broadcasting Law, before changing the norms of regulation, the government must consider the benefit and welfare of the community. Responsive Law by Phillipe Nonet and Philip Selznick reveals that laws and regulations exist for the welfare of society. This can be achieved by the Court by using a Consensualism, Prudential, and Futuristic interpretation of the lawsuit. The Constitutional Court further elaborated these methods by explaining:

a) Consensualism from Sotirios B. and James F. emphasizes the importance of interpretation based on the context of the current development of society;

b) Prudential from Philip Bobbit who emphasized that interpretation must pay attention to cost and benefits due to the enactment of regulation; and

c) Futuristic from Sudikno M. and A. Pitlo who pay attention to interpretation also need to anticipate the next condition. ${ }^{23}$

\footnotetext{
21 “Tandatangani Petisi.” Change.Org, 2020, www.change.org/p/menkominfo-platejohnny-tolak-gugatan-rcti-biarkanpublik-tampil-live-di-media-sosial-biarkanrakyatmainmedsos. Accessed 11 Oct. 2020.

${ }^{22}$ Besar, "UTILITARIANISME DAN TUJUAN PERKEMBANGAN HUKUM MULTIMEDIA DI INDONESIA,” Business Law, June 2016, https://business-law.binus.ac.id/2016/06/30/utilitarianisme-dan-tujuan-perkembangan-hukum-multimediadi-indonesia/

${ }^{23}$ Muhammad Reza Winata and Oly Viana Agustine, "REKONEKSI HUKUM DAN DISRUPSI TEKNOLOGI MELALUI TAFSIR KONSTITUSIONAL MENDUKUNG PEMBANGUNAN EKONOMI BERKELANJUTAN,” Jurnal Legislasi Indonesia 16, no. 4 (2019).
} 
This method of interpretation can be used by the Constitutional Court to review the lawsuit. Furthermore, the Constitutional Court in examining laws that are different, but interlinked with one another, needs to pay attention to these four substances, namely:

a) Technical aspects or technological aspects, in the world of broadcasting, broadcasting institutions use the frequency spectrum as well as the broadcast digitization system

b) Legal aspects of broadcasting licensing regulated in the Broadcasting Law and other implementing regulations.

c) Legal aspects of broadcast programs include rules regarding the permissibility and prohibition of broadcast programs, program standards, and broadcast content, as well as other legal rules that broadcast practitioners must obey.

d) Aspects of criminal law, where the provisions stipulated in the Broadcasting Law contain criminal provisions imposed on violators of broadcasting practices. ${ }^{24}$

This is where the existence of the Constitutional Court (MK) through the legal mechanism of constitutional review of laws against the 1945 Constitution as stipulated in Article 24C paragraph (1) of the 1945 Constitution and Article 10 of Law Number 24 of 2003 as amended by Law -Law Number 8 of 2011 concerning the Constitutional Court. The authority of the Constitutional Court can become a legal mechanism that stimulates harmonization between legal development and digital development. For this reason, as Jimly Asshidiqie stated, the functions of the Constitutional Court can be said to include:

a) The guardian of the constitution;

b) Interpreter of the constitution (the interpreter of the constitution);

c) The guardian of democratization

d) The protector of human rights

e) The guardian of ideology.

In the context of this article, the Constitutional Court should also function as harmonizer norms and community development. ${ }^{25}$ The Constitutional Court decision that accommodates the legal needs of society for technological developments will become a medium for 'reconnection' between law and technology so that it is consistent in harmony so that the Court can carry out its function as harmonizer norms and community development.

\section{Implementation Of Consensualism, Prudential And Futuristics In The Revision Of The Broadcasting Law}

The audio-visual sector faces challenges and opportunities brought about by the increasing internationalization of the market and the rapid advancement of information technology and communication technology. This caused the distinction between traditional telecommunications and modern broadcasting to be increasingly blurred. Therefore, a regulation that will be the scope of all audiovisual services such as non-linear services (Video on Demand), OTT services, and other media services is needed. Such a regulation must cover all audiovisual media services - regardless of the technology used to deliver or how the service is viewed, so that there is no confusion in interpretation or legal uncertainty.

If we do a comparative study with other countries, Europe or the European Union has launched an Audio Visual Media Service Directive (AVMSD) regulation which regulates the

\footnotetext{
${ }^{24}$ Denico Doly, "URGENSI PERUBAHAN UNDANG-UNDANG NOMOR 32 TAHUN 2002 TENTANG PENYIARAN," Negara Hukum 4, no. 2 (November 2, 2013).

${ }^{25}$ Jimly Asshiddiqie, “Mahkamah Konstitusi Dan Pengujian Undang-Undang, ” Jurnal Hukum IUS QUIA IUSTUM 11, no. 27 (September 16, 2004): 1-6, https://doi.org/10.20885/iustum.vol11.iss27.art1.
} 
coordination of national legislation across Europe on all audiovisual media for both traditional TV broadcasts and on-demand services. The law was last signed by legislators on 14 November 2018 and published in the Official Journal of the European Union on 28 November 2018. After being published in the Official Journal, EU countries have 21 months to convert them into national laws, ${ }^{26}$ the Audio-Visual Media Services (AVMSD) Directive which regulates broadcasting and audiovisual media services reflects the European Union's struggle to accept the convergence phenomenon and highlights current legal uncertainties, following the objectives of the urgency of the EU in making AVMSD regulations, namely:

a) Provide rules for shaping technological developments

b) Creating an equal playing field for any emerging audiovisual media

c) Preserving cultural diversity

d) Protect children and consumers

e) Maintain media pluralism

f) Combating racial and religious hatred

g) Ensure the independence of national media regulators.

This can be exemplified by the Constitutional Court in applying a futuristic interpretation in legal decision making to anticipate what will happen in the development of broadcasting law on OTT services and the era of digitalization in the future. From the case above, we can conclude that the main problems in Indonesia's Broadcasting Law are the deflecting focus of the regulating content itself. The State and KPI has averted from the main focus on how Broadcasting Law in Indonesia should actually be developed in accordance to the rapid digitalization era, instead of regulating content that is considered to be excessive by the State. Law Number 32 of 2002 concerning Broadcasting and KPI's regulation should be adjusted to adapt its regulations to technological developments and society so that OTT services can become the scope of the Broadcasting Law. Therefore, we can see this AVMSD Law as a reference in revising the Broadcasting Law.

The main elements of The Audiovisual Media Services Directive are:

a) A comprehensive framework that reduces regulatory burdens, but includes all audiovisual media services;

b) Modernizing television advertising regulations that can increase the ability to finance audiovisual content;

c) New features such as obligations that encourage media service providers to increase access for the visually or hearing impaired public.

On 24 April 2013 the Commission published a Green Paper, 'Preparation for a Completely Convergent Audiovisual World: Growth, Creation and Values', with the aim of provoking a broad public discussion about the implications of the ongoing transformation of the audiovisual media landscape, characterized by by increasing convergence of media services, and the way these services are consumed and delivered. This can be a way for Indonesia's government to interpret consensualism so that the legal products produced are the results of discussions with the community itself. This is in line with Article 96 of Law Number 12 Year 2011 concerning the Establishment of Laws and Regulations which emphasizes the existence of public participation in the formation of a Laws and Regulations. ${ }^{27}$ The Directive also contains special rules to protect minors from inappropriate on-demand audiovisual media services. These rules are complemented by 1998 and 2006 recommendations on the protection of minors and human

\footnotetext{
${ }^{26}$ European Commission, “Audiovisual Media Services Directive (AVMSD),” Shaping Europe's digital future - European Commission, 2018, https://ec.europa.eu/digital-single-market/en/audiovisual-media-services-directive-avmsd.

${ }^{27}$ Law Number 12 of 2011 concerning Establishment of Laws and Regulations
} 
dignity, and an 'Internet Safety' program that promotes safer use of the Internet and new online technologies, especially for children. Rather than regulating excessive content types, the Indonesian Broadcasting Law should have a better "filter" setting to overcome this problem.

Creative Europe was formed in line with the Europe 2020 strategy for smart, inclusive and sustainable growth. Through this Creative Europe Program, the European Commission hopes to support the European audiovisual, cultural and creative sectors to be able to contribute to cultural diversity as well as to economic growth by creating new jobs in Europe. The aim of this program is also to strengthen cross-border cooperation between creative sectors within the European Union, and also outside the European Union. Furthermore, there are sub-programs from Creative Europe which are the "Culture" and "MEDIA" programs. Under the MEDIA program, the European Commission provides financial assistance for the development, promotion and distribution of audiovisual works in Europe and beyond. It provides funds for the development, promotion (for markets and festivals), distribution of works, and the construction of cinema networks in Europe and beyond. In addition, Creative Europe also has a cross-sectoral strategy that includes a new financial guarantee fund for the cultural and creative industries that will be introduced post 2014. Creative Europe is part of the Multiannual Financial Framework which sets the parameters for the budget. the entire European Union for the period 2014 - 2020 such as promoting online content distribution, media literacy and media pluralism.

The basis of media literacy is an activity that emphasizes the educational aspect of the community so that they know how to access, select programs that are useful and according to existing needs. Therefore, media literacy is a fundamental skill for all vulnerable people in general. The European Union considers the media literacy or media literacy as an important factor for the growth of active citizens in the current information society era. And also the importance of pluralism in the media is as a form of transparency, freedom and diversity in the media. Where in overcoming these two things, the European Union established the Center for Media Pluralism and Media Freedom (CMPF) in 2012. This CMPF is a further step as an effort by the European Commission to not only improve protection against media pluralism and media freedom in Europe but also to encourage these goals, especially defending the interests of European culture in the WHO (World Trade Organization). ${ }^{28}$

From these programs and regulations set by the European Commission, Indonesia can learn to emulate some of these things in the discussion of the next Broadcasting Bill.

The scope of the established law should be able to accommodate all problems that may arise from misuse of broadcasting. The product of the law itself is expected to cover each subproblem of broadcasting so as to allow the existence of several law products that complement one another, both in conventional broadcasting and internet-based broadcasting such as OTT services. Likewise, Indonesia can focus this OTT service in a positive direction by keeping up with the times but still guided by existing laws in Indonesia.

\section{Conclusion}

1. Currently, OTT services cannot be the scope of Law Number 32 of 2002 concerning Broadcasting because the content in the Law revolves around broadcasting using the public sphere so that it will be unconstitutional, violating the public's right to an opinion and slowing the economy if OTT services incorporated into Law Number 32 of 2002 concerning Broadcasting. Therefore, there is an urgency to change the Broadcasting Law so that OTT services can become the scope of this legal umbrella.

\footnotetext{
${ }^{28}$ European Commission, "COMMISSION STAFF WORKING DOCUMENT: Reporting on the Application of Articles 13, 16 and 17 of Directive 2010/13/EU: For the Period 2011-2014 as Regards Non-Linear Services (Article 13) and 2013-2014 as Regards Linear Services (Articles 16 and 17)," October 13, 2020.
} 
2. The Constitutional Court conducts a Judicial Review on the development of legal relations with the digitalization era through the authority to examine the constitutionality of Law number 32 of 2002 concerning Broadcasting against the 1945 Constitution. Over The Top (OTT). This is because digitalization is a significant development and is felt directly in social life, but it turns out that law cannot always respond to technological developments quickly and precisely, so it has a negative impact on several parties both in social and economic terms. For this reason, the Constitutional Court as the last interpreter of the constitution can construct a synergy between law and technological developments to maintain socio-economic equality in the community in using Over The Top (OTT) services.

3. The preference for the method of constitutional interpretation of the Constitutional Court on technological developments in the era of digitalization, can support sustainable economic development, create clear legal protection so that no party feels disadvantaged, uses interpretations: Consensualism, interpretation based on the context of current developments in society, Prudential, interpretations pay attention to the impact of profit and loss, and Futuristic, an interpretation that projects and anticipates future conditions. This method can be used as a guideline for the People's Representative Council (DPR RI) and the Government in drafting laws and regulations that accommodate the development of digital technology to take advantage of its existence in the socio-economic aspect of society, without violating constitutional rights and human rights of the wider community.

\section{Bibliography}

A. Books

Asshiddiqie, Jimly. Konstitusi Dan Konstitusionalisme Indonesia. Jakarta: Konstitusi Press, 2005. Bentham, Jeremy. An Introduction to the Principles of Morals and Legislation. Printed in the Year 1780, and Now First Published. by Jeremy Bentham ... London: Printed For T. Payne, And Son, 1789.

Makarim, Edmon. Pengantar Hukum Telematika: Suatu Kompilasi Kajian. Jakarta: Raja Grafindo Persada, 2010.

Mochtar, Zainal Arifin. Lembaga Negara Independen, Dinamika Perkembangan Dan Urgensi Penatannya Kembali Pasca-Amandemen Konstitusi. Jakarta: Rajawali Press, 2016.

Rahayu, and Regulator. Menegakkan Kedaulatan Telekomunikasi \& Penyiaran Di Indonesia: Peta Persoalan Dan Rekomendasi Kebijakan. Depok, Sleman, Yogyakarta: Pemantau Regulasi Dan Regulator Media, 2015.

B. Journals

Abdullah, Assyari. "Pola Kebijakan Digitalisasi Penyiaran Di Indonesia." ARISTO 8, no. 1 (January 1, 2020): 82. https://doi.org/10.24269/ars.v8i1.2092.

Arliman S, Laurensius. "Komisi Penyiaran Indonesia Sebagai State Auxialiary Bodies Yang Menjamin Siaran Yang Layak Bagi Anak." Veritas et Justitia 3, no. 1 (2017). https://doi.org/https://doi.org/10.25123/vej.2528.

Asshiddiqie, Jimly. "Mahkamah Konstitusi Dan Pengujian Undang-Undang." Jurnal Hukum IUS QUIA IUSTUM 11, no. 27 (September 16, 2004): 1-6. https://doi.org/10.20885/iustum.vol11.iss27.art1 .

Aswandi, Ririn, Putri Rofifah Nabilah Muchsin, and Muhammad Sultan. "Perlindungan Data Dan Informasi Pribadi Melalui Indonesian Data Protection System (Idps)." LEGISLATIF 3, no. 2 (June 2020).

Doly, Denico. "Urgensi Perubahan Undang-Undang Nomor 32 Tahun 2002 Tentang Penyiaran." Negara Hukum 4, no. 2 (November 2, 2013). 
European Expert Group on Sexuality Education. "Sexuality Education - What Is It?" Sex Education 16, no. 4 (November 26, 2015): 427-31. https://doi.org/10.1080/14681811.2015.1100599.

Fajrudin. "Arti Penting Konstitusi Dalam Sebuah Negara." Al Qisthas: Jurnal Hukum Dan $\begin{array}{llllll}\text { Politik } & 8, & \text { no. } & \text { 2019). }\end{array}$ http://jurnal.uinbanten.ac.id/index.php/alqisthas/article/view/1613.

Genus, Audley, and Andy Stirling. "Collingridge and the Dilemma of Control: Towards Responsible and Accountable Innovation." Research Policy 47, no. 1 (February 2018): 6169. https://doi.org/10.1016/j.respol.2017.09.012.

Nugroho, F.H. Edy. "Kemampuan Hukum Dalam Mengantisipasi Perkembangan Teknologi." Jurnal Paradigma Hukum Pembangunan 1, no. 2 (August 31, 2016).

Riyanto, Mochamad. "Arah Revisi Undang-Undang Penyiaran Dalam Perspektif Hukum Ekonomi." SPEKTRUM HUKUM 16, no. 1 (July 15, 2019): 60. https://doi.org/10.35973/sh.v16i1.1127.

Rojko, Andreja. "Industry 4.0 Concept: Background and Overview." International Journal of Interactive Mobile Technologies (IJIM) 11, no. 5 (July 24, 2017): 77. https://doi.org/10.3991/ijim.v11i5.7072.

Sanusi, Kus Rizkianto, and Kanti Rahayu. "Hukum Yang Responsif Terhadap Revolusi Industri 4.0 Dalam Perspektif Pancasila." Prosiding Seminar Nasional Hukum Transendental 2019, 2019.

Schwab, Klaus. The Fourth Industrial Revolution. New York: Crown Business, 2017.

Sidik, Suyanto. "Dampak Undang-Undang Informasi Dan Transaksi Elektronik (Uu Ite) Terhadap Perubahan Hukum Dan Sosial Dalam Masyarakat." Jurnal Ilmiah WIDYA 1, no. 1 (2013).

Winata, Muhammad Reza, and Oly Viana Agustine. "Rekoneksi Hukum Dan Disrupsi Teknologi Melalui Tafsir Konstitusional Mendukung Pembangunan Ekonomi Berkelanjutan.” Jurnal Legislasi Indonesia 16, no. 4 (2019).

C. Regulations

Constitution of the Republic of Indonesia.

Indonesian Broadcasting Commission Regulation Number 01/P/KPI/03/2012 concerning Guidelines for Broadcasting Conduct.

Law Number 12 of 2011 concerning Establishment of Laws and Regulations.

Law Number 24 of 1997 concerning Broadcasting.

Law Number 24 of 2003 concerning the Constitutional Court.

Law Number 32 Year 2002 concerning Broadcasting/

D. Internet

Besar. "Utilitarianisme Dan Tujuan Perkembangan Hukum Multimedia Di Indonesia." Business Law, June 2016. https://business-law.binus.ac.id/2016/06/30/utilitarianisme-dan-tujuanperkembangan-hukum-multimedia-di-indonesia/.

European Commission. "Audiovisual Media Services Directive (AVMSD)." Shaping Europe's digital future - European Commission, 2018. https://ec.europa.eu/digital-singlemarket/en/audiovisual-media-services-directive-avmsd.

Indonesia, C. N. N. "Penyiaran Digital Indonesia Tertinggal Dibanding Malaysia." CNN Indonesia, July 27, 2020. https://www.cnnindonesia.com/teknologi/20200725073801-185528807/penyiaran-digital-indonesia-tertinggal-dibanding-malaysia.

Komisi Penyiaran Indonesia. "Dasar Pembentukan." Komisi Penyiaran Indonesia, 2017. http://www.kpi.go.id/index.php/id/tentang-kpi/dasar-pembentukan.

Nasution, Dara. "Tolak Gugatan RCTI! Siapa Aja Bebas Tampil Live Di Medsos." Change.org, 2020. https://www.change.org/p/menkominfo-platejohnny-tolak-gugatan-rcti-biarkanpublik-tampil-live-di-media-sosial-biarkanrakyatmainmedsos.

Putri, Adelia. "Riset: 84 Persen Remaja Indonesia Belum Mendapatkan Pendidikan Seks." detikHealth, July 18, 2019. https://health.detik.com/berita-detikhealth/d-4629842/riset-84persen-remaja-indonesia-belum-mendapatkan-pendidikan-seks. 
Ridhoi, Muhammad Ahsan. "Geger Gugatan RCTI - INews Dan Perlunya UU Baru Atur Siaran OTT - Telaah Katadata.Co.Id.” katadata.co.id, August 31, 2020. https://katadata.co.id/muhammadridhoi/indepth/5f4c50fddb2a0/geger-gugatan-rcti-inewsdan-perlunya-uu-baru-atur-siaran-ott.

Teguh, Irfan. "Alat Kekuasaan Bernama TVRI.” Edited by Ivan Aulia Ahsan. tirto.id, August 24, 2018. https://tirto.id/alat-kekuasaan-bernama-tvri-cUvu. 
